\title{
PENGARUH PENGGUNAAN MEDIA KOMIK TERHADAP HASIL BELAJAR SISWA PADA MATERI VIRUS KELAS X DI SMA NEGERI 2 GOWA
}

\author{
Sri Inka Ramdhani ${ }^{1}$ \\ Universitas Muhammadiyah Makassar, sri.inkaramdhani78@gmail.com \\ Nurul Magfirah ${ }^{2}$ \\ Universitas Muhammadiyah Makassar, Nurul.magfirah@unismuh.ac.id \\ Hilmi Hambali ${ }^{2}$ \\ Universitas Muhammadiyah Makassar, hilmihambali@unismuh.ac.id
}

\begin{abstract}
ABSTRAK
Penelitian ini bertujuan untuk mengetahui pengaruh penggunaan media komik terhadap hasil belajar siswa pada materi virus kelas X di SMA Negeri 2 Gowa. Jenis penelitian ini adalah eksperimen semu (quasi eksperiment) dengan desain penelitian yang digunakan yaitu posttest-only control group desaign, yaitu setelah proses pembelajaran dilakukan posttest untuk mengetahui hasil belajar siswa setelah diberikan perlakuan. Populasi penelitian ini adalah seluruh siswa kelas X dan sampel pada penelitian ini adalah kelas X IPA 3 sebagai kelas eksperimen dan kelas X IPA 6 sebagai kelas kontrol. Data yang dikumpulkan mengenai hasil belajar siswa dianalisis menggunakan analisis satistik deskriptif dan inferensial. Hasil penelitian menunjukkan bahwa rata-rata hasil belajar siswa pada kelas eksperimen yaitu 77,02 sedangkan pada kelas kontrol yaitu 69,38. Hasil analisis data uji hipotesis menggunakan Independent Sample t-Test didapatkan Sig sebesar 0,003 dan nilai tingkat signifikansinya $(\alpha)$ adalah 0,05 , hal ini menunjukkan bahwa nilai Sig lebih kecil dari nilai tingkat signifikansi $(\alpha)$. Berdasarkan hasil penelitian tersebut maka dapat disimpulkan bahwa terdapat pengaruh penggunaan media komik terhadap hasil belajar siswa pada materi virus.
\end{abstract}

\section{ABSTRACK}

This research aims to determine the influence of the use of comic media to students ' learning outcomes virus materials in class $X$ at SMA Negeri 2 Gowa. This type of research is a pseudo experiment (quasi experiment) with the research design used is posttest-only control group design, After the learning process is conducted posttest to learn the students 'learning outcomes after treatment. The population of this study is all grade $X$ students and samples on this study were X IPA 3 classes as experimental classes and X IPA 6 class as the control class. Data gathered about student learning outcomes is analyzed using descriptive and inferential satistic analyses. The results showed that the average student learning results of the 
experiment class was 77.02 while the control class was 69.38 with a great influence of 7.64.Data gathered about student learning outcomes is analyzed using descriptive and inferential satistic analyses. The results showed that the average student learning results of the experiment class was 77.02 while the control class was 69.38 with a great influence of 7.64. The results of the analysis of hypothesized test data using the Independent Sample of T-Test acquired Sig of 0.003 and its significance level value $(\alpha)$ is 0.05 , it indicates that the value of the Sig is smaller than the value of significance ( $\alpha$ ). Based on the results of the study it can be concluded that there is a influence of the use of comic media to student learning outcomes on the viral material.

Kata kunci : Media Komik; Hasil Belajar.

\section{PENDAHULUAN}

Terselenggaranya pendidikan akan membuat manusia saling memberikan informasi, memperdalam suatu ilmu pengetahuan, memperbaiki cara berpikir individu, dan meningkatkan kreativitas. Manusia dan pendidikan tidak dapat dipisahkan, sebab pendidikan merupakan kunci dari masa depan manusia yang telah diberikan akal untuk berpikir. Undangundang Sistem Pendidikan Nasional Nomor 20 tahun 2003 pasal 1 ayat 1 menyatakan bahwa "Pendidikan adalah usaha sadar dan terencana untuk mewujudkan suasana belajar dan proses pembelajaran agar siswa secara aktif mengembangkan potensi dirinya untuk memiliki kekuatan spiritual keagamaan, pengendalian dirinya, kepribadian, kecerdasan, akhlak mulia, serta keterampilan yang diperlukan dirinya, masyarakat, bangsa dan negara."

Peningkatan mutu pendidikan perlu dilakukan untuk memecahkan persoalan pendidikan di Indonesia. Mutu pendidikan harus diperhatikan untuk mencapai tujuan pendidikan sedangkan mutu itu sendiri dapat dilihat dari keberhasilan siswa selama mengikuti pembelajaran. Seperti yang telah dijelaskan dalam UndangUndang tersebut memberikan gambaran mengenai definisi dan tujuan pendidikan nasional. Menurut Hasbullah (2013) tujuan pendidikan nasional dilakukan untuk mencerdaskan kehidupan bangsa dan mengembangkan manusia Indonesia seutuhnya. Untuk itu, siswa dan guru diharapkan dapat mengembangkan seluruh potensi yang ada pada diri siswa, sehingga dapat mencapai tujuan pembelajaran yang diharapkan. Guru 
dituntut untuk melakukan segala usaha demi terciptanya suasana belajar yang mendukung dan secara aktif melibatkan siswa dalam proses pembelajaran.

Pendidikan pada dasarnya bermaksud untuk membantu siswa untuk memberdayakan potensi dalam dirinya atau menumbuhkembangkan potensi-potensi yang ada dalam dirinya yang dimana sering diartikan sebagai memanusiakan manusia untuk memberikan bantuan secara sadar dalam diri siswa (Neolaka dan Amalia, 2017). Pendidikan ditentukan dengan proses yang ada di dalam kelas, dimana guru memegang peranan penting dalam proses pembelajaran untuk memenuhi kebutuhan berbagai aspek siswa. Terlepas dari hal itu, sebuah perubahan yang terjadi pada diri siswa tidak akan lepas dari bagaimana cara guru menyampaikan materi pembelajarannya.

Proses pembelajaran akan sangat membantu keefektifan dan penyampaian pesan serta isi pelajaran dalam meningkatkan proses dan hasil belajar jika menggunakan media pembelajaran. Media sebagai salah satu sumber belajar yang dapat menyalurkan pesan sehingga dapat mengatasi berbagai permasalahan dalam pembelajaran seperti perbedaan gaya belajar, minat, atau intelegensi dapat diatasi dengan pemanfaatan media (Mais, 2016).

Lewat media guru dapat berkomunikasi dengan siswa, materi yang tidak dapat dijelaskan oleh guru melalui bahasa verbal akan terwakili oleh media yang digunakan. Menurut Sumiharsono dan Hasanah (2017) pemanfaatan media dalam proses belajar mengajar dapat memberikan pengaruh yang besar terhadap proses belajar mengajar. Materi yang bersifat abstrak dan sulit akan menjadi konkret apabila dapat dijelaskan secara langsung kepada siswa yang disederhanakan melalui penggunaan media pembelajaran. Media pembelajaran dapat meningkatkan proses belajar-mengajar, pada umumnya hasil belajar siswa dengan menggunakan media pembelajaran akan tahan lama mengendap sehingga kualitas pembelajaran memiliki nilai yang tinggi.

Meskipun media pembelajaran mampu memberikan suasana belajar yang lebih yang hidup di dalam kelas, namun melihat pada kenyataan sekarang ini masih terdapat 
permasalahan dalam proses pembelajaran salah satunya adalah masih banyak guru yang kurang menyadari pemanfaatan media pembelajaran dengan baik. Hal tersebut terbukti dengan hasil observasi awal di kelas X SMA Negeri 2 Gowa bahwa guru hanya menggunakan media pembelajaran yang monoton dalam proses pembelajaran seperti buku paket dan papan tulis. Penggunaan media pembelajaran dengan papan tulis dan buku teks pelajaran belum mampu memberikan pengaruh yang cukup terhadap peningkatan hasil belajar siswa.

Pembelajaran seperti ini
tentunya $\quad$ tidak
membonankan, dan kurang bermakna
bagi siswa. Siswa lebih cenderung
kurang termotivasi r untuk
memperhatikan pembelajaran
sehingga melakukan kegiatan lain
seperti bermain, berbicara dengan
teman sebangkunya, dan bahkan
berjalan di dalam kelas yang dapat
membuat siswa kurang memahami
materi pembelajaran. Salah satu
materinya adalah virus, materi tersebut
sulit dipahami karena memiliki konsep
yang bersifat abstrak. Siswa hanya

membayangkan atau berimajinasi karena materi tersebut tidak dapat diamati langsung oleh indra penglihatan manusia, seperti bagaimana bentuk dan ukuran pada virus itu sendiri serta bagaimana virus dapat berkembang biak. Padahal seharusnya dalam mempelajari biologi sangat dibutuhkan penunjang berupa media pembelajaran sehingga materi pembelajaran dapat tersampaikan dengan baik. Untuk itu dibutuhkan guru yang kreatif dalam memilih media pembelajaran agar proses belajar mengajar jadi lebih efektif dan efisien.

Permasalahan dalam proses pembelajaran tersebut tentu akan berdampak pada hasil belajar yang diperoleh siswa. Hal ini terbukti dari hasil wawancara yang dilakukan bersama guru Biologi SMA Negeri 2 Gowa, bahwa hasil nilai dan mutu belajar Biologi kelas X SMA Negeri 2 Gowa masih rendah dan masih ada yang tidak mencapai nilai KKM yang diterapkan. Nilai rata-rata yang didapatkan siswa masih ada di bawah 60, yaitu $60 \%$ yang tidak tuntas, sedangkan nilai ketuntasan yang diterapkan oleh SMA Negeri 2 Gowa adalah siswa dinyatakan tuntas dalam 
belajar Biologi apabila mencapai nilai KKM 75.

Dewasa ini, telah dikembangkan berbagai macam media terutama yang lebih bersifat visual. Pengembangan ini berupaya mendukung potensi siswa secara umum yang secara alami dalam belajar lebih banyak menggunakan indra penglihatan yaitu mata. Selain penekanan pada sisi visual, media yang lebih didukung untuk dikembangkan adalah media yang mendukung pembelajaran yang menyenangkan. Hal ini dimaksudkan agar siswa mau mengikuti pembelajaran dengan antusias, sehingga materi pembelajaran akan lebih mudah terekam pada memori siswa.

Media yang menarik tidak akan memberikan tekanan kepada siswa dalam belajar sehingga mereka akan tetap nyaman saat belajar tanpa adanya unsur keterpaksaan. Salah satu bentuk media itu adalah media komik pembelajaran. Mengapa komik? Karena anak-anak, sebagaimana orang dewasa juga menyukai komik. Komik mempunyai sifat sederhana, jelas dan mudah dipahami sehingga menjadi media yang informatif dan edukatif.
Menurut Waluyanto (2005) komik adalah bentuk komunikasi visual yang mempunyai kekuatan untuk menyampaikan informasi secara popular dan mudah dimengerti karena komik memadukan gambar dan tulisan yang dirangkai dalam suatu alur cerita agar mudah diserap.

Media komik diberikan agar siswa dapat lebih mudah untuk memahami materi virus, materi pembelajaran menggunakan komik dituangkan secara lebih menarik dalam ilustrasi gambar kartun dan menyeluruh dengan alur jelas. Oleh karena itu, jika media yang menyenangkan ini digunakan dalam proses pembelajaran akan membawa suasana menyenangkan dalam proses pembelajaran. Jika siswa mendapati suasana yang menyenangkan dalam proses pembelajaran, mereka akan terlibat total dalam proses pembelajaran itu. Keterlibatan secara total ini penting untuk melahirkan hasil belajar yang sukses. Hal tersebut sejalan dengan hasil penelitian dari Mashitoh (2012) bahwa terdapat perbedaan hasil belajar siswa yang signifikan antara siswa yang menggunakan media komik dengan yang tidak menggunakan media komik 
pada pembelajaran yang dapat dilihat berdasarkan uji hipotesis diperoleh $(7,57>2,00)$ maka $\mathrm{H} 1$ diterima yang dengan kata lain penggunaan media komik memberikan pengaruh terhadap hasil belajar siswa.

Berdasarkan latar belakang di atas, maka rumusan masalah dalam penelitian ini adalah (1) Apakah ada pengaruh penggunaan media komik terhadap hasil belajar siswa pada materi virus kelas $\mathrm{X}$ di SMA Negeri 2 Gowa? Dan (2) Bagaimana hasil belajar siswa dengan menggunakan media komik pada materi virus kelas $\mathrm{X}$ di SMA Negeri 2 Gowa?

Tujuan dari penelitian ini adalah (1) Untuk mengetahui apakah ada pengaruh penggunaan media komik terhadap hasil belajar siswa pada materi virus kelas $X$ di SMA Negeri 2 Gowa. Dan (2) Untuk mengetahui bagaimana hasil belajar siswa dengan menggunakan media komik pada materi virus kelas X di SMA Negeri 2 Gowa

\section{METODE PENELITIAN}

Jenis penelitian yang digunakan yaitu Quasi Experiment dengan menggunakan desain penelitian Posttest Only Control Group Design.
Penelitian dilaksanakan di kelas $\mathrm{X}$ MIA SMA Negeri 2 Gowa pada bulan September 2019 semester ganjil tahun ajaran 2019/2020. Bidang kajian yang diteliti terkhusus pada mata pelajaran Biologi. Sampel yang digunakan dalam penelitian ini terdiri dari dua kelas yaitu kelas X MIA 6 sebagai kelas kontrol dengan jumlah 34 orang dan kelas X MIA 3 sebagai kelas eksperimen dengan jumlah 34.

Prosedur atau langkah-langkah dari penelitian ini yaitu (1) Observasi, dilakukan di Sekolah SMA Negeri 2 Gowa, diperoleh informasi yaitu, mengenai hasil belajar biologi siswa kelas X, jumlah kelas X, jumlah siswa dalam satu kelas, proses pembelajaran biologi, dan lain-lain. Hasil observasi tersebut didapatkan dari wawancara dengan salah satu guru biologi di sekolah. (2) Perencanaan/ persiapan. Tahap persiapan adalah tahap dalam memulai suatu kegiatan sebelum peneliti langsung kelapangan untuk mengumpulkan data, peneliti terlebih dahulu menyiapkan RPP, silabus, dan perangkat lain yang dibutuhkan, serta mengurus surat izin untuk mengadakan penelitian kepada pihakpihak yang bersangkutan

Pelaksanaan. Berdasarkan pada silabus 
dan RPP, secara umum pelaksanaan perlakuan dalam penelitian ini terdiri dari 3 kali pertemuan. Dengan 1 kali pertemuan untuk posttest dan 3 kali pertemuan untuk memberikan materi yang akan diajarkan (4) Evaluasi. Evaluasi yang dilakukan pada penelitian ini dengan memberikan Posttest untuk mengetahui hasil belajar siswa kelas X SMA Negeri 2 Gowa .

Pada penelitian ini teknik pengumpulan data yang digunakan adalah teknik tes tertulis berupa data hasil belajar yang diperoleh dari lembar soal. Jenis teknik tes tertulis digunakan sebagai tes hasil belajar, yaitu tes untuk mengukur pencapaian seseorang setelah mempelajari sesuatu. Analisis yang dilakukan dalam penelitian ini adalah analisis statistik deskriptif dan statistik inferensial.

\section{HASIL DAN PEMBAHASAN}

Berdasarkan hasil posttest dari analisis statistik deskriptif yang diperoleh menunjukkan nilai rata-rata kelas eksperimen lebih tinggi dibandingkan nilai rata-rata pada kelas kontrol. Setelah dilakukan uji analisis statistik inferensial hasil uji hipotesis pada data posttest dengan menggunakan uji Independent Sample $t$ Test diperoleh nilai signifikan 0,003 yang dapat disimpulkan bahwa terdapat pengaruh yang signifikan dari penggunaan media komik terhadap hasil belajar siswa pada materi virus kelas X di SMA Negeri 2 Gowa.

Berikut tabel ke empat analisis statistik deskriptif dan sattistik inferensial

Tabel 1 Data Statistik Hasil Belajar Siswa Pada Kelas Eksperimen Yang Diajar Dengan menggunakan Media Komik

\begin{tabular}{|c|c|}
\hline Statistik & Nilai Kelas Eksperimen \\
\hline Ukuran Sampel & 34 \\
\hline Skor Ideal & 100 \\
\hline Skor Maksimum & 90 \\
\hline Skor Minimum & 63 \\
\hline Rentang Skor & 37 \\
\hline Skor rata-rata & 77,02 \\
\hline
\end{tabular}

Tabel 2 Data Statistik Hasil Belajar Siswa Pada Kelas Kontrol

\begin{tabular}{|c|c|}
\hline Statistik & Nilai Kelas Kontrol \\
\hline Ukuran Sampel & 34 \\
\hline Skor Ideal & 100 \\
\hline Skor Maksimum & 87 \\
\hline Skor Minimum & 47 \\
\hline Rentang Skor & 40 \\
\hline Skor rata-rata & 69,38 \\
\hline
\end{tabular}

Tabel 3 Distribusi Frekuensi Nilai Hasil Belajar Siswa Kelas Eksperimen Yang Diajar Dengan menggunakan Media Komik 


\begin{tabular}{|c|c|c|c|c|}
\hline No. & $\begin{array}{c}\text { Interval } \\
\text { Nilai }\end{array}$ & Frekuensi & Persentase & $\begin{array}{c}\text { Kategori } \\
\text { Hasil } \\
\text { Belajar }\end{array}$ \\
\hline 1. & $93-100$ & 0 & 0 & $\begin{array}{l}\text { Sangat } \\
\text { baik }\end{array}$ \\
\hline 2. & $84-92$ & 7 & $20,59 \%$ & Baik \\
\hline 3. & $75-83$ & 14 & $41,18 \%$ & Cukup \\
\hline 4. & $<75$ & 13 & $38,23 \%$ & Kurang \\
\hline \multicolumn{2}{|c|}{ Jumlah } & 34 & $100 \%$ & \\
\hline
\end{tabular}

Tabel 4 Distribusi dan Persentase Hasil Belajar Siswa

\begin{tabular}{|c|c|c|c|c|}
\hline No. & $\begin{array}{c}\text { Interval } \\
\text { Nilai }\end{array}$ & Frekuensi & Persentase & $\begin{array}{c}\text { Kategori } \\
\text { Hasil } \\
\text { Belajar }\end{array}$ \\
\hline 1. & $93-100$ & 0 & 0 & $\begin{array}{c}\text { Sangat } \\
\text { baik }\end{array}$ \\
\hline 2. & $84-92$ & 1 & $2,94 \%$ & Baik \\
\hline 3. & $75-83$ & 12 & $35,30 \%$ & Cukup \\
\hline 4. & $<75$ & 21 & $61,76 \%$ & Kurang \\
\hline \multicolumn{6}{|c|}{ Jumlah } & 34 & $100 \%$ & \\
\hline
\end{tabular}

Tabel 5 Deskriptif Ketuntasan Hasil Belajar Kelas Eksperimen

\begin{tabular}{|c|c|c|c|}
\hline Nilai Hasil & Kategori & Frekuensi & Persen \\
\hline$<75$ & Tidak tuntas & 13 & $38,23 \%$ \\
\hline
\end{tabular}

Berdasarkan hasil analisis,

Siswa yang diberikan perlakuan dengan menggunakan media pembelajaran berupa komik merasa tidak bosan dan menjadi lebih semangat dalam pembelajaran. Dengan demikian, adanya perbedaan hasil belajar pada kelas eksperimen dan kelas kontrol dikarenakan pemberian perlakuan yang berbeda pada kedua kelas tersebut. Kegiatan pembelajaran dilakukan pada kelas kontrol guru hanya menggunakan media buku teks dan metode ceramah yang dominan berpusat pada guru yang biasa digunakan saat proses pembelajaran. Selain itu, siswa

\begin{tabular}{|c|c|c|c|}
\hline$\geq 75$ & Tuntas & 21 & $61,77 \%$ \\
\hline \multicolumn{2}{|c|}{ Jumlah } & $\mathbf{3 4}$ & $\mathbf{1 0 0}$ \\
\hline \multicolumn{2}{|c|}{} \\
\hline \multicolumn{2}{|c|}{. } \\
\hline
\end{tabular}

Tabel 6 Deskriptif Ketuntasan Hasil Belajar Kelas Kontrol

\begin{tabular}{|c|c|c|c|}
\hline Nilai Hasil & Kategori & Frekuensi & Persen \\
\hline$<75$ & Tidak tuntas & 21 & $61,76 \%$ \\
\hline$\geq 75$ & Tuntas & 13 & $38,24 \%$ \\
\hline \multicolumn{2}{|c|}{ Jumlah } & $\mathbf{3 4}$ & $\mathbf{1 0 0}$ \\
\hline
\end{tabular}

Tabel 7 Rekapitulasi Hasil Uji Statistik Posttest Kelas Eksperimen dan Kelas Kontrol

\begin{tabular}{|c|c|c|}
\hline \multirow{2}{*}{ Uji Statistik } & \multicolumn{2}{|c|}{ Posttest } \\
\cline { 2 - 3 } & $\begin{array}{c}\text { Kelas } \\
\text { Eksperimen }\end{array}$ & $\begin{array}{c}\text { Kelas } \\
\text { Kontrol }\end{array}$ \\
\hline Normalitas & $\mathbf{0 , 0 9 6}$ & $\mathbf{0 , 1 0 4}$ \\
\hline Homogenitas & \multicolumn{2}{|c|}{$\mathbf{0 , 2 4 2}$} \\
\hline Hipotesis & \multicolumn{2}{|c|}{$\mathbf{0 , 0 0 3}$} \\
\hline
\end{tabular}

cenderung bosan dengan buku teks yang sebagian besar hanya berupa tulisan dan minim gambar dengan tampilan buku teks tersebut yang kurang menarik bagi siswa untuk mengikuti proses pembelajaran. Hal tersebut menjadi beberapa faktor yang menjadi penyebab rendahnya hasil belajar pada siswa pada kelas kontrol.

Kegiatan pembelajaran pada kelas eksperimen menggunakan media komik, siswa aktif dalam pembelajaran dan antusias saat proses pembelajaran berlangsung. Pada saat guru membagikan media komik ke masing-masing kelompok, terlihat tertarik pada media komik tersebut 
karena bagi siswa penggunaan media komik merupakan suatu hal yang baru saat proses pembelajaran, sehingga menjadikan siswa lebih termotivasi dalam proses pembelajaran. Dilihat dari hasil observasi aktivitas siswa, pada saat kegiatan diskusi kelompok setiap siswa bekerja sama dengan kelompoknya masing-masing untuk menjawab soal yang terdapat pada lembar kerja siswa. Selain itu, pada saat kegiatan tanya jawab dan guru memberikan kesempatan untuk bertanya beberapa siswa sebagai perwakilan untuk bertanya kemudian menaggapi pertanyaan berdasarkan apa yang telah siswa baca dan hasil diskusi dengan teman kelompoknya. Hal ini sejalan dengan penelitian yang dilakukan oleh Mashitoh (2012) bahwa komik sebagai media pembelajaran dapat menjadikan lebih aktif dalam proses pembelajaran (student center), maka komik dijadikan salah satu upaya dalam meningkatkan hasil belajar siswa terutama mata pelajaran biologi.

Faktor yang mempengaruhi hasil belajar siswa pada kelas eksperimen meningkat dibandingkan dengan kelas kontrol dikarenakan media komik membekali dengan kemampuan membaca yang menyenangkan dan menghibur bagi pembaca. Media komik disajikan dengan daya tarik yang terdapat pada ilustrasi gambar menarik serta memiliki alur cerita yang runtut dan teratur memudahkan untuk diingat kembali. Media yang menarik tidak akan memberikan tekanan kepada peserta didik dalam belajar sehingga mereka akan tetap nyaman saat belajar tanpa adanya unsur keterpaksaan. Selain tampilannya menarik dan penyajian materinya mudah dipahami, karakter tokoh dalam komik dapat digunakan sebagai teladan untuk menyampaikan pesan nilai-nilai karakter bagi pembaca.

$$
\text { Pembelajaran yang }
$$
menyenangkan menyebabkan tumbuhnya respon positif dari siswa yang secara langsung berdampak pada peningkatan hasil belajar. Jika siswa mendapati suasana yang menyenangkan dalam proses pembelajaran, mereka akan terlibat total dalam proses pembelajaran itu. Keterlibatan secara total ini penting untuk melahirkan hasil belajar yang sukses. Selain itu, media komik virus 
sebagai sumber belajar ini dapat menggantikan kedudukan dari buku teks atau sebagai pendamping buku teks dalam pembelajaran, memiliki ukuran yang tipis menjadikan media komik mudah dibawa, dan dapat dijadikan media pembelajaran mandiri karena komik memiliki isi cerita yang tidak membosankan dan juga diangkat dari fenomena yang sering terjadi seperti yang dikatakan Novisilta (2016) bahwa komik membuat siswa lebih senang dengan media pembelajaran yang bergambar juga lebih mudah dipahami karena pemilihan jalan cerita dari komik yang dibuat mengambil tema yang sering terjadi pada kehidupan sehari-hari. Dengan penggunaan media komik pada pembelajaran, maka siswa merasa senang, santai, dan tidak membuat siswa merasa tegang dalam

\section{KESIMPULAN}

Berdasarkan hasil penelitian yang diperoleh, maka dapat disimpulkan sebagai berikut.

1. Ada pengaruh penggunaan media komik terhadap hasil belajar siswa pada materi virus kelas $\mathrm{X}$ di SMA Negeri 2 Gowa setelah menggunakan mengikuti pembelajaran. Sehingga hasil belajar yang dicapai siswa menjadi optimal dibandingkan kelas kontrol yang pembelajarannya tanpa berbantu media komik.

$\begin{array}{ccc} & \text { Penggunaan media dalam } \\ \text { proses belajar mengajar dapat }\end{array}$ memegang peranan yang penting sebagai alat bantu untuk menciptakan proses belajar yang menyenangkan sehingga siswa dapat dengan mudah memahami materi yang disampaikan oleh guru. Namun, dari kelebihan media komik yang dipaparkan juga terdapat kekurangan antara lain (1) dari segi bentuk dan gambar masih sederhana, dan (2) dan pada saat penggunaannya peneliti sebaiknya menyediakan komik dalam jumlah yang lebih banyak agar masingmasing siswa dapat membaca komik dengan tenang.

media komik dilihat dari hasil uji statistik inferensial dengan menggunakan uji Independent Sample $T$ Test yang diperoleh nilai sig sebesar 0,003 lebih kecil dari tingkat signifikasi $(\alpha)$ yaitu 0,05 yang artinya terdapat pengaruh.

2. Berdasarkan uji statistik deskriptif diperoleh nilai rata-rata hasil posttest 
pada kelas eksperimen lebih tinggi yaitu sebesar 77,02 dibandingkan dengan nilai rata-rata hasil posttest pada kelas kontrol yaitu sebesar 69,38. Hal tersebut disebabkan karena adanya perbedaan pemberian perlakuan dalam proses pembelajaran, yaitu pada kelas eksperimen proses pembelajaran menggunakan media komik.

\section{UCAPAN TERIMA KASIH}

Ucapan terima kasih kepada seluruh yang telah terlibat pada penelitian saya semoga allah selalu merahmati semuanya, terkhusus kepada keluarga saya bapak ibu tercinta berserta keluarga besar Prodi pendidikan Biologi Universitas Muhamadiyah Makassar.

\section{DAFTAR PUSTAKA}

Hasbullah. 2013. Dasar-Dasar Ilmu Pendidikan. PT Rajagrafindo Persada : Depok.
Mashitoh, S. 2012. Pengaruh Penggunaan Media Komik terhadap Hasil Belajar Kognitif Siswa pada Konsep Sistem Pencernaan Makanan. Skripsi. Universitas Islam Syarif Hidayatullah : Jakarta.

Mais, A. 2016. Media Pembelajaran. Pustaka Abadi : Jawa Timur.

Neolaka, A \& Neolaka, G. Landasan Pendidikan Dasar Pengenalan Diri Sendiri Menuju Perubahan Hidup. PT. Kharisma Putra Utama : Depok.

Novisilta, Feronika Cici. 2016. Pengaruh Media Komik Terhadap Minat Belajar dan Hasil Belajar Fisika Siswa Kelas VII SMP Katolik 2 W.R Soepratman Borong Tongkok di Kutai Barat Pada Materi Konsep Zat. Skripsi. Universitas sanata dharma Yogyakarta : Yogyakarta.

Sumiharsono, M. R. \& Hasanah, H. 2017. Media Pembelajaran. Pustaka Abadi : Jatim. 